\title{
Ecological Footprints
}

\author{
Steven N. Handel
}

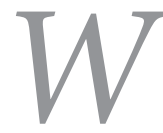

e spend our quiet time thinking and talking about our landscape projects, how we will plan and install them, and what we wish them to become. But what if the table was turned, and the landscape was sentient? What would it think about us, its human workers and care-givers?

They are coming.

I hear their footsteps, their turning wheels on my soil, their loud chattering. I see their eyes, searching from place to place, hoping to see something new or happily familiar. Sometimes they rush through; sometimes it is a slow passage, with stops, meanders and rest stops. But they are coming by the hundreds, these visitors to my landscape.

What will they see?

Will they just see my wide fields and undulating slopes, my rough clusters of trees and meadows in irregular patches, or will they bend down and see my microscale details, the hundreds of small pieces of habitats and surfaces that make up the whole. Will they see the scale of a single plant stem, the mottled surface, the stones and rotten logs, and tiny creatures that link together, allowing the living diversity here to grow and persist? Will they see how things change, hour to hour, and month to month, then through the decades, or will they think that I am fixed and immutable? Will they see me differently on each visit, slowly growing and changing, just as they do? Will their memories of each trip be different or will I quickly seem routine?

What will they hear?

Will it be the winds shearing through the canopy, the rustling of the lowland willows, or the creaking limbs of my oldest trees? Will they hear the calls of my hundreds of birds, each species different in pitch and melody? Will they hear the differences in songs from the winter and from the summer, as life stages and threats change with new needs? Will they hear the streams, carving out a new floodplain during winter storms or the cracking mud on the banks as

Ecological Restoration Vol. 36, No. 1, 2018

ISSN 1522-4740 E-ISSN 1543-4079

(O)2018 by the Board of Regents of the University of Wisconsin System. the summer heat shrivels my surface? Will they hear the sounds of the night, the thousands of insects and bats as the evening's drama plays out, its battles hidden from their human eyesight? Will they hear the voices and music of the people on my paths, or will they find my silent places, where they can find hard-won solitude and be filled only with their thoughts?

What will they smell?

Will they be enveloped by the sage or the mint's pungent odors and wonder why these smells evolved? Will they press close against a wildflower's bloom to capture its sweetness? Will they smell the sudden life that fills a vernal pool as the days begin lengthening or the rank odors of my marshlands as the spring thaw is underway? Will they sense the heaviness of the air and the wet ground as the snowmelt courses by, and will they smell the dryness of wilted leaves of a hot August afternoon?

What will they remember?

Will they remember the single scaly lizard warming on a trail-side rock, or the pale colors on the spring hills as the first rains paint away the late winter's drab browns? Will they remember the first time they see a hummingbird hover over a scarlet flower or see a hunting hawk plunge from the sky, seeking a feathered mid-day meal? Will they remember the petals of spring flowering trees on the paths or the crunch of oak and hickory leaves on the fall paths during a quiet walk, or will it be the dripping coolness of the ferns that cover the wettest cliffs? Will they remember how the meadows fill with butterflies in one month but then are emptied the next, or how the colors of the slopes change from season to season so even much loved areas seem new on each return trip? Will they remember a flash of some small mammal as it runs to the bush or the slow gliding of the turtles in my pond as they warm in the sun? Will they remember how I change from path to path and from moment to moment until the words to describe me accurately must be complex and varied, and my simple name masks a long living drama with countless scenes and players? Will they take the time to see these things and to remember? 
When will they return?

Will I make them curious enough to come back? Will they want to know me better? Will they feel that the next visit will give them something new and unexpected or fill them with a new emotion that has been long missing? Will they bring their families to share the experience, or know that their world of friends can be enlarged here? Will they want to return to learn and enrich their own lives? Will they want to return to help improve me and make me healthier, help keep me going into the future? When they think about their lives and where they live will I be in their thoughts?

Will I change them, my visitors?

They are coming to me. We will be together for many, many years.

I am the landscape of the new restoration project.

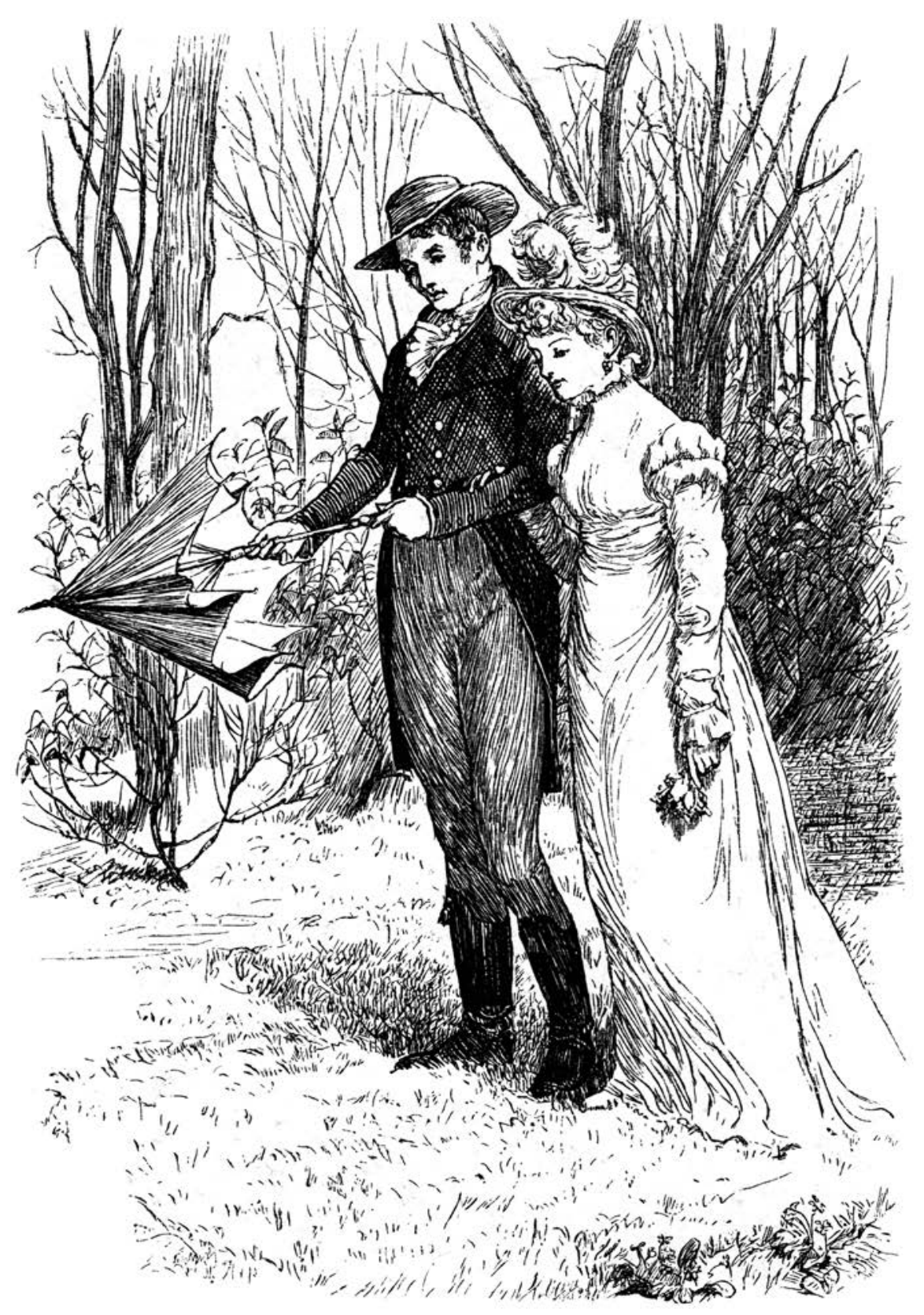

A couple strolling through a park. H.B.R. Caldecott. 1889. A Personal Memoir. London, UK: Sampson Low, Marston, Searle and Rivington, Limited. The Florida Center for Instructional Technology, fcit.usf.edu. 